\title{
Chapter 4 \\ Economic Crisis, Turbulence and the Resilience of Innovation: Insights from the Atlantic Maritime Cluster
}

\author{
Hugo Pinto, Elvira Uyarra, Mercedes Bleda, Carla Nogueira, \\ and Helena Almeida
}

\subsection{Introduction}

The recent economic turbulence has demonstrated that countries, regions and even firms have different capacity for coping with external shocks. Many fail and are damaged, and ultimately devastated by the impacts of the crisis. On the other hand, some of them are able to resist the shocks, adapt quickly and recover their trajectories, and in some cases even generate new growth trajectories using their relative advantages to deal with turbulent environments (Archibugi et al. 2013; Makkonen 2013; Paunov 2012).

\section{H. Pinto $(\square)$}

Centre for Social Studies, University of Coimbra, Coimbra, Portugal

CIEO - Research Centre for Spatial and Organizational Dynamics, University of Algarve, Faro, Portugal

Faculty of Economics, University of Algarve, Faro, Portugal

e-mail: hpinto@ces.uc.pt

E. Uyarra

Manchester Institute of Innovation Research (MIoIR), Alliance Manchester Business School, Manchester, UK

M. Bleda

Manchester Institute of Innovation Research (MIoIR), Alliance Manchester Business School, University of Manchester, Manchester, UK

C. Nogueira

CIEO - Research Centre for Spatial and Organizational Dynamics, University of Algarve, Faro, Portugal

H. Almeida

CIEO - Research Centre for Spatial and Organizational Dynamics, University of Algarve, Faro, Portugal

Faculty of Economics, University of Algarve, Faro, Portugal 
This capacity to respond to shocks and disruptions is the target of increasing policy and academic attention. In regional studies, much emphasis has been placed on the concept of 'resilience' as a capacity of complex adaptive systems to deal with internal shocks and external disruptions (Boschma 2015; Simmie and Martin 2010). Resilience in the study of territorial socio-economic systems has abandoned an engineering and ecological perspective to become an evolutionary concept, focused on the processes of selection, survival, and adaptation, as well as on the adaptability of different types of systems to build new dynamic trajectories by overcoming locksin and path dependencies (Martin and Sunley 2015). Innovation, knowledge production and exchange, are key contributors to resilience, by creating a variety of opportunities to deal with the challenges that organizations, firms, regions and countries face in highly dynamic and turbulent environments (Simmie 2014). The perception of innovation as a procyclical activity which follows the trend of macroeconomic variables such as GDP and investment, is contested by studies showing firms continuing or increasing their innovative efforts despite the economic downturn (Frenz and Prevezer 2012).

During the years of the economic crisis, innovation and new knowledge creation within systems of innovation, in particular the extent to which new knowledge is generated and diffused across the relevant actors, allowed socioeconomic systems to generate variety and adapt to change (Boschma 2015). Since resilience is often referred to as an attribute of a specific system, some authors suggest that innovation systems, in particular regional innovation systems, are good candidates as a unit of analysis for this capacity (Pinto and Pereira 2014).

In this chapter, we are suggesting a new approach. That resilience is not only seen as an attribute of systems but also as an attribute of the innovation process. 'Resilience of innovation' thus refers to the capacity of an innovation process to maintain or accelerate its functions when facing an internal disruption and/or an external shock. Resilience of innovation, as a complex phenomenon, is a multi-level characteristic that applies to systems at the macro-level, i.e. to individual countries and regions, at the meso-level, in particular focusing networks, clusters and regional innovation systems, and at micro-level of organizations, that is to innovation actors such as firms, universities and other public research organizations, and innovation governance bodies.

As we have already indicated, the focus of this chapter is on the resilience of innovation at the organizational level. Inspired by complex adaptive innovation systems (Cooke 2013) and evolutionary ideas (Boschma and Martin 2010), our goal is the identification of factors that are important to encourage the process of new knowledge generation and exchange which underpins the resilience of innovation processes at the level of the organization. For this purpose, we focus on organizations within a particular regional innovation cluster: the maritime cluster in the European Atlantic Area. In particular, we centre on organizations in this cluster that experienced an increased or unchanged demand for innovation and knowledgebased services, our interest is on those organizations that showed resilience in front of the disturbances consequence of the economic downturn.

For our analysis, we draw upon the results of a survey on knowledge exchange and innovation, which was built in 2014 to detect and assess the specific knowledge 
needs of entities engaged in maritime cluster in the Atlantic Area, as well as to investigate the provision of innovation and knowledge related exchange services in the sector. ${ }^{1}$

We provide parametric and non-parametric evidence of the differences in the provision and utilisation of these services and of the main factors that influence the resilience of innovation of organizations within the cluster, as well as, several suggestions for innovation policies that can be derived from the analysis.

\subsection{Regional Resilience and the Dynamics of Innovation}

The concept of resilience is associated to an increase of economic, political and environmental risks and the lack of emergent processes in post-industrial society that have accentuated economic and social inequalities in the regions (Davoudi et al. 2012). The interest in the regions' resilience emerged from a general feeling of uncertainty and insecurity and the search for solutions for adaptation and survival in response to a complex and diverse set of external shocks, including the financial crises. The intersection of the economy with the environment has increased the sense of vulnerability and, therefore, has stimulated the search for new ways to understand the adaptive capacity of regions (Alexander 2013).

Simmie and Martin (2010: 28) defined resilience as an “... 'adaptive ability' to the differential ability of a region or local firms' to adapt to changes and shocks in the competitive market, technological policy and related conditions that the evolutionary dynamics and trajectories of that regional or local economy over time".

To date, work on resilient regions has focused more on conceptual and empirical analysis from high performing regions. An established fact today is that innovation is an essential foundation for resilience and effective social and economic development (Hamdouch and Depret 2012).

The increased focus on regions as the best geographical scale for a knowledge economy points to the importance of geographical proximity and regional resources in stimulating the innovation capability and competitiveness of firms (Cooke and Leydesdorff 2006). The regional innovation narrative is largely based on success stories of specific industrial agglomerations or regional networks of SMEs and industrial clusters (Tödtling and Trippl 2005). In many cases, learning and knowledge transfer are highly localised (Boschma 2005). It is recognized that important elements of the process of innovation become regionalized (Howells 2005). One of the reasons is because innovation occurs in a specific institutional, political and social context (Rodríguez-Pose 2013).

The general perception of the region as the main locus for economic interaction and innovation brought relevance to the notion of "regional innovation system". The

\footnotetext{
${ }^{1}$ The survey was part of the European project KIMERAA (available at www.kimeraa.eu) aimed at developing economic niches of excellence through the creation of strong linkages between firms and science organizations within the marine sciences and maritime activities.
} 
rise in the popularity of the concept of regional innovation systems has been in part driven by the increased intensity of international competition in a globalising economy, the apparent shortcomings of traditional regional development models and policies, and the emergence of successful clusters of firms and industries in many regions around the world (Uyarra and Flanagan 2012).

As suggested by Doloreux (2002) the concept of regional innovation systems is difficult to delimitate but usually it is understood as a set of private and public interests, institutions and organizations, their relationships that are encouraging the generation, use and dissemination of knowledge. This set produces pervasive and systemic effects that encourage firms within a regional context to develop specific forms of capital that reinforce regional innovation capability and competitiveness (Gertler 2003). RISs are premised on innovation being a geographical process and innovation capabilities being sustained through regional communities that share common knowledge bases (Asheim et al. 2005). The RIS literature supported this argument and showed that firms' innovative activity is based on localized resources such as a specialized labour market and labour force, subcontractor and supplier systems, local learning processes and spillover effects, local traditions for co-operation and entrepreneurial attitude, supporting agencies and organizations and the presence of customers and users (Asheim et al. 2011). On other hand, innovation can occur more easily through organized proximity, regardless of the geographical concentration (Torre and Rallet 2005). The "organized" characteristic refers to the arranged nature of human activities and not to the fact that one may belong to one organisation in particular. It goes beyond the mere cognitive dimensions resting in two key aspects: the belonging and the similarity. Clusters are seen as relevant in contributing to "related variety" (Frenken et al. 2007) and helping the economic interactions between regional actors.

Clusters stimulate sectoral specialisation, cognitive and geographical proximity, competition and cooperation, leading to spillovers and synergies within a regional innovation system. Innovation activities benefit from the concentration of economic activities of similar and related firms in a cluster and facilitate knowledge spillovers and stimulate various forms of adaptation, learning and innovation (Skålholt and Thune 2013). The maritime cluster is of particular interest for the European Union as an area of potential economic valorisation connecting traditional sectors with science-based activities (Pinto et al. 2015a, b).

The mechanisms of knowledge production and exchange among the different agents that form a regional innovation system or a cluster are varied. They involve multiple processes or activities and different types and forms of knowledge flows and interactions among them. There is also an ample spectrum of innovation and knowledge exchange support services aimed at both encouraging knowledge transfer and reducing the barriers that all actors, but in particular SMEs, usually face in carrying out innovation (Pinto and Fernández-Esquinas 2013). The literature has amply stressed the importance of small business services, most notably the so called "real services" (Bellini 2003), namely support for business development, manufacturing and innovation processes, generally delivered directly with companies to stimulate knowledge transfer. Shapira et al. (2015) discuss the relevance of 
technology extension service (TES), defined as assistance provided directly to enterprises to foster technological modernization and improvement, with a focus on established SMEs.

Peripheral areas tend to present a less developed innovation support ecosystem, in particular because they are characterized by a large number of SMEs in less intensive technology sectors. SMEs in those areas may therefore find access to specialist knowledge provision problematic (Fernández-Esquinas et al. 2015). Given this 'knowledge intensive business services-poor' landscape, universities and public research organizations tend to play a stronger role as providers of specialist knowledge for regional companies (Pinto et al. 2015a, b).

Many factors influence the extent to which firms are able to benefit from the presence of an innovation support ecosystem. For instance, structural factors such as size and R\&D expenditure affect the degree to which SMEs, and firms in general draw from external sources of knowledge. Sector specific dynamics also play a significant role in shaping the type and variety of knowledge interactions (Laursen and Salter 2006). Regarding typical barriers or constraints to the establishment of knowledge exchange interactions, communication barriers, appropriability problems, lack of absorptive capacity, and cultural differences, are the most frequently quoted in the literature (for a review see Perkmann et al. 2013).

As it is widely recognised in the literature, innovation is more difficult for SMEs than for larger firms: they usually have fewer resources, have less capacity to invest in $\mathrm{R} \& \mathrm{D}$, and are in general more affected by uncertainty and innovation barriers (Bluhm and Schmidt 2008). The integration of SMEs into knowledge sharing networks and innovation systems, particularly at the regional level, constitutes a way to address these innovation difficulties (Teixeira et al. 2008). However, it is not often that SMEs truly engage in innovation networks, and in the cases in which they do their interaction tends to be mostly with business partners an much less with other knowledge providers in the network (i.e. universities, public research organizations and technology centres, public authorities and large firms). Whilst collaboration with business partners, such as customers and suppliers, is important to stimulate innovation in SMEs (Hassink 1997), knowledge exchange with other agents is also key as it allows SMEs to make use of all the potential sources of knowledge offered by their regional innovation systems environment (Zeng et al. 2010).

\subsection{Methodological Notes}

As indicated in the introduction, our analysis uses information collected from an online survey built with Qualtrics. The survey_provided in English, Portuguese and Spanish to facilitate understanding and encourage a high completion rate-was sent to potential users and/or providers of innovation or knowledge related exchange services operating in the maritime sector. These were 1743 entities located in France, the UK, Ireland, Spain, and Portugal (667 with valid e-mail contact). 
The survey was active in the first half of 2014. The total number of responses received during this period was 102 from 491 entities which were able to receive the email with the invitation to complete the survey online. The response rate $(20.7 \%)$ is acceptable in particular given the generality of the questions included in the survey and the heterogeneity in terms of type, sector, and characteristics of the entities forming the target population.

The survey was structured in four sections. The first section, inspired in the literature on university-industry interactions (Perkmann et al. 2013) included a set of general questions about the use (or lack thereof) of the following innovation or knowledge exchange and support services/schemes:

- Technical services and facilities (e.g. for certification, testing, prototyping, calibration)

- Business services and intelligence (marketing, access to markets, exporting)

- Innovation management advice (product/process innovation) and training

- Other training services related to innovation

- Incubation facilities and services (e.g. in science parks)

- R\&D services

- Funding for co-operative R\&D projects

- Services for inter-firm collaboration and networking (e.g. cluster associations)

- Provision of risk capital (venture capital, seed capital)

- Services/advice related to intellectual property protection

- Student placements or other type of mobility schemes between industry and universities/research organizations

- Other (please specify)

The category 'Other' was provided to allow respondents to add services or schemes not covered in the previous list.

The first section also included questions about potential reasons for not using these services, such as unawareness of their availability, high cost of the services, low quality and/or sophistication, lack of alignment with the organizations' needs, level of bureaucracy involved with their use, and the effects that the economic crisis has had on the organizations' investment capacity in this type of services.

The second section included questions in relation to the provision of the previously listed knowledge exchange services or schemes during the last 3 years. Organizations operating in the maritime sector that identified themselves as providers were enquired about:

- Their main clients and the percentage that they represent in the organization's portfolio (private firms, universities, technology centres and other research organizations, other public organizations, not for profit organizations, ...);

- The location of their clients (local/regional, national, international);

- If they had detected any changes in the demand of these knowledge services;

- And in which ways they normally advertise their services (visits to clients, media, website, mailing lists, workshops...). 
The third section of the survey focused on issues related to the use of specific knowledge services or schemes during the last 3 years. In particular, we asked organizations that identified themselves as users of these services:

- The importance of these services and activities for the organization (from 1 not important to 5 extremely important);

- The types of providers of the services they use (private firms, universities, technology centres and other research organizations, other public organizations, business angels,...);

- The location of these providers (local/regional, national, international);

- An assessment of the service (from 1 very poor to 5 very good) in terms of its quality, technical expertise of the staff delivering the service, its cost and accessibility, and its alignment with the organization's needs;

- And in which way their demand for these services had varied in the last 3 years.

The final section of the survey included a set of questions about the particular characteristics of the respondent organizations: their type, size, location, and the maritime sector to which they belong. ${ }^{2}$

\subsection{Knowledge Exchange and Resilience of Innovation}

\subsubsection{Some Descriptive Results}

The organizations that completed the survey belong to a high variety of sub-sectors within the maritime sector: sailing associations, sea biotechnology, health/wellbeing, maritime tourism, processing of sea salt, seaweed extracts services, fishing software, subsea and diving works, processing of fishing products, sails manufacturing, and wave energy sector. Most of the 102 organizations that completed the survey were located in different regions of Portugal (58\%) followed by Ireland (13\%), Spain (11\%), France $(11 \%)$, the UK $(6 \%)$, and others $(1 \%)$.

The respondents regarded different organization types (Fig. 4.1). Private enterprises $(42.6 \%)$ were the most represented, followed by universities or research centres $(22.1 \%)$, and not for profit organizations (11.8\%). Regarding size, $40.6 \%$ had less than 10 employees, 18.9\% 10-50 employees, 13.0\% 50-250 employees, $15.9 \%$ 250-500 employees, and $11.6 \%$ more than 500 employees. $34 \%$ of the organizations did not used knowledge exchange activities or services used in the last 3 years. Many of the users of the listed services are also providers of some innovation support services themselves (see Table 4.1).

When prompted about the degree of importance of these activities for innovation, a few activities were more often reported by respondents as important or very

\footnotetext{
${ }^{2}$ The descriptive statistics report "Knowledge needs and innovation in the maritime economy" with interim data collection is available in the project website.
} 


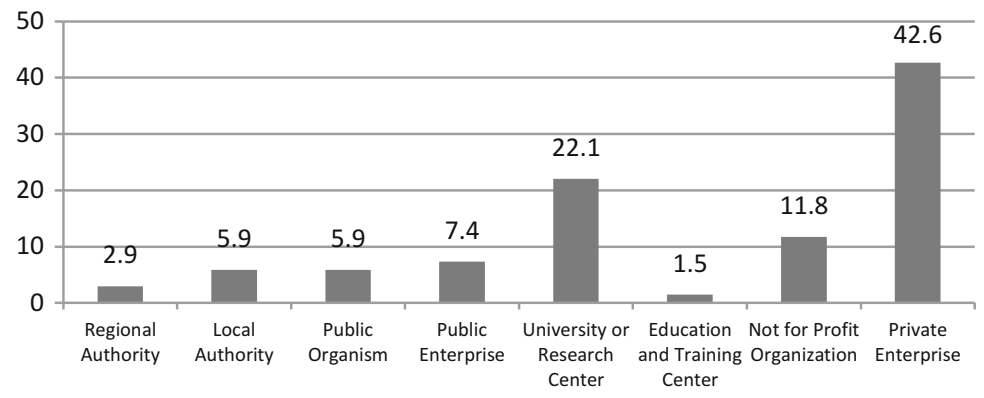

Fig. 4.1 Types of respondent organizations (in \% of total answers). Source: Own elaboration

Table 4.1 Use and provision of knowledge exchange activities

\begin{tabular}{l|l|l|l}
\hline \multirow{2}{*}{} & \multicolumn{3}{|l}{$\begin{array}{l}\text { Does your organization provide any knowledge/exchange } \\
\text { services? }\end{array}$} \\
\hline $\begin{array}{l}\text { Does your organization use any } \\
\text { knowledge/exchange services? }\end{array}$ & No & No & Yes \\
\cline { 2 - 4 } & Yes & $33 \%$ & $1 \%$ \\
\hline
\end{tabular}

Source: Own elaboration

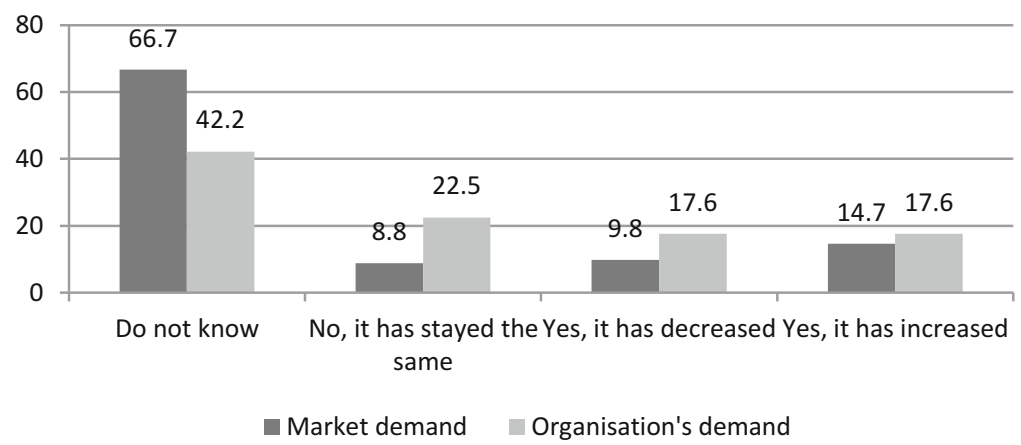

Fig. 4.2 Variations of market and organization's demands. Source: Own elaboration

important, namely funding for cooperative $R \& D$ projects and $R \& D$ services, followed by services for inter-firm collaboration and networking.

Two crucial variables for our study are the ones that look for the variations in market demand for innovation and knowledge services (In your experience, has the demand for these services varied in the last 3 years?) and the organization's demand (How has your demand for these services varied in the last 3 years?) (Fig. 4.2). The first element to retain is a high level of ignorance about this market (66.7\% claim not to know what is happening in the market while $42.2 \%$ is unaware of the internal demand dynamics). Nonetheless, for those that are aware of what is happening, a clear majority considers that demand has stayed the same or even increased. 


\subsubsection{Parametric and Non-Parametric Evidence}

Based in the KIMERAA survey we have selected specific variables to deepen the analysis using parametric and non-parametric techniques. ${ }^{3}$ The goal was to get statistical evidence of the differences between groups of the organizations, namely, by size $(18.6 \%$ have more than 250 workers), type $(15.7 \%$ are academic versus remaining non-academic), and knowledge management (36.3\% are organizations that provide or administer knowledge exchange services or schemes).

We present below the descriptive statistics for the selected variables (Table 4.2). Particularly relevant are the variables that try to detect the breadth of services used and provided by the organizations. These are count variables that sum if the organization uses/provides a particular type of service from the defined list. ${ }^{4}$

We tried to test if organizations with different size have the same utilization and provision of innovation and knowledge-based services. The breadth of services used and provided is presented in Fig. 4.3.

We rejected the hypotheses of equal means by different sizes, meaning that organization with different number of workers have provided and used a different breadth of mechanisms. ${ }^{5}$ Both utilisation and provision grow with size but reach its maximum in medium-sized firms (50-250 workers) declining in bigger organizations.

Table 4.2 Descriptive statistics

\begin{tabular}{l|l|l|l|l|l}
\hline & $\mathrm{N}$ & Minimum & Maximum & Mean & Deviation \\
\hline $\begin{array}{l}\text { USE_Variety of knowledge exchange } \\
\text { activities or services used in the last } \\
3 \text { years }\end{array}$ & 102 & 0.00 & 11.00 & 3.2941 & 3.28690 \\
\hline $\begin{array}{l}\text { PROVISION_Variety of knowledge } \\
\text { exchange activities or services provided } \\
\text { in the last 3 years }\end{array}$ & 102 & 0.00 & 11.00 & 1.5490 & 2.58950 \\
$\begin{array}{l}\text { CLIENT_EXPORT_Clients located } \\
\text { internationally (\%) }\end{array}$ & 102 & 0.00 & 91.00 & 4.8824 & 16.98881 \\
\hline $\begin{array}{l}\text { CLIENT_FIRM—Clients are MNEs and } \\
\text { SMEs (\%) }\end{array}$ & 102 & 0.00 & 100.00 & 14.803 & 31.513 \\
\hline $\begin{array}{l}\text { EVAL_Assessment of the quality of } \\
\text { services used }\end{array}$ & 102 & 0.00 & 30.00 & 11.5686 & 11.27646 \\
\hline
\end{tabular}

Source: Own elaboration

\footnotetext{
${ }^{3}$ We used for this section the IBM SPSS Statistics 21.

${ }^{4}$ These two variables do not follow a normal distribution. The graphical intuition provided but the Q-Q plots and histograms is confirmed by the Kolmogorov-Smirnov test (1.869 and 3.759 compared to $\mathrm{n}>40$ and Sig $1 \%=0.25205$ ) (see histograms in Appendix).

${ }^{5}$ Looking for the homogeneity of variances, Levene test does not reject its null hypotheses of groups having homogeneous variances for the variable "utilisation". In this case ANOVA is valid (results in Appendix). But for "provision", the test rejects this H0 meaning that we need to use a non-parametric technique. We used Kruskal-Wallis that reinforced the findings (table test is also presented in Appendix).
} 


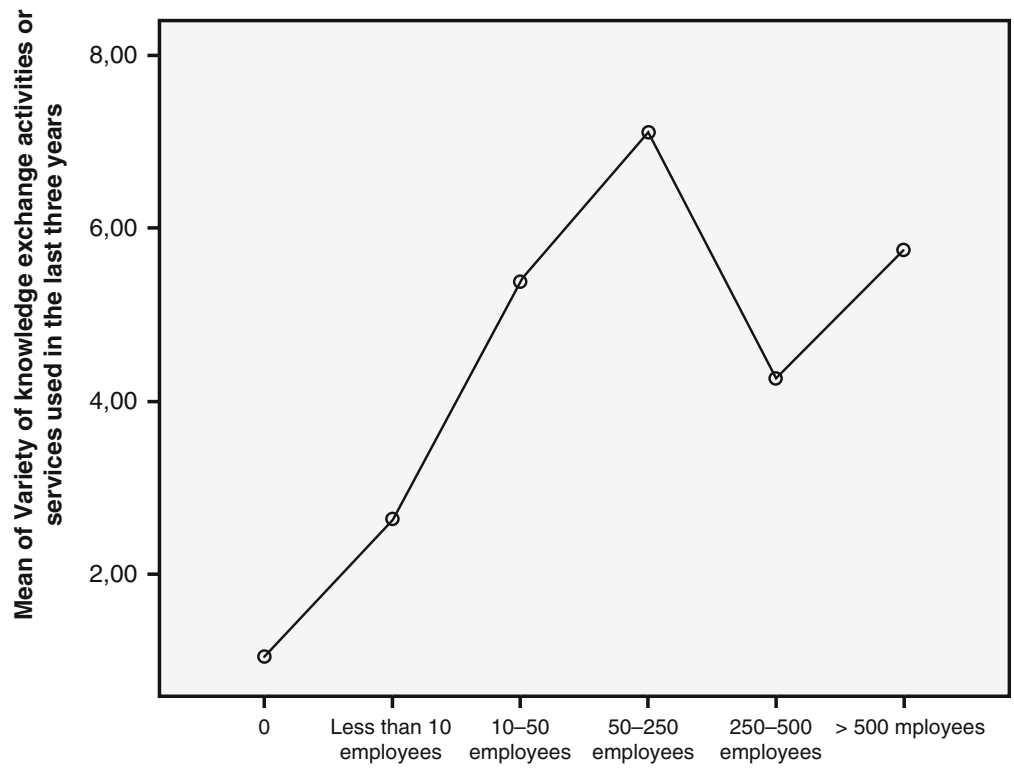

16. What is the size of your organization?

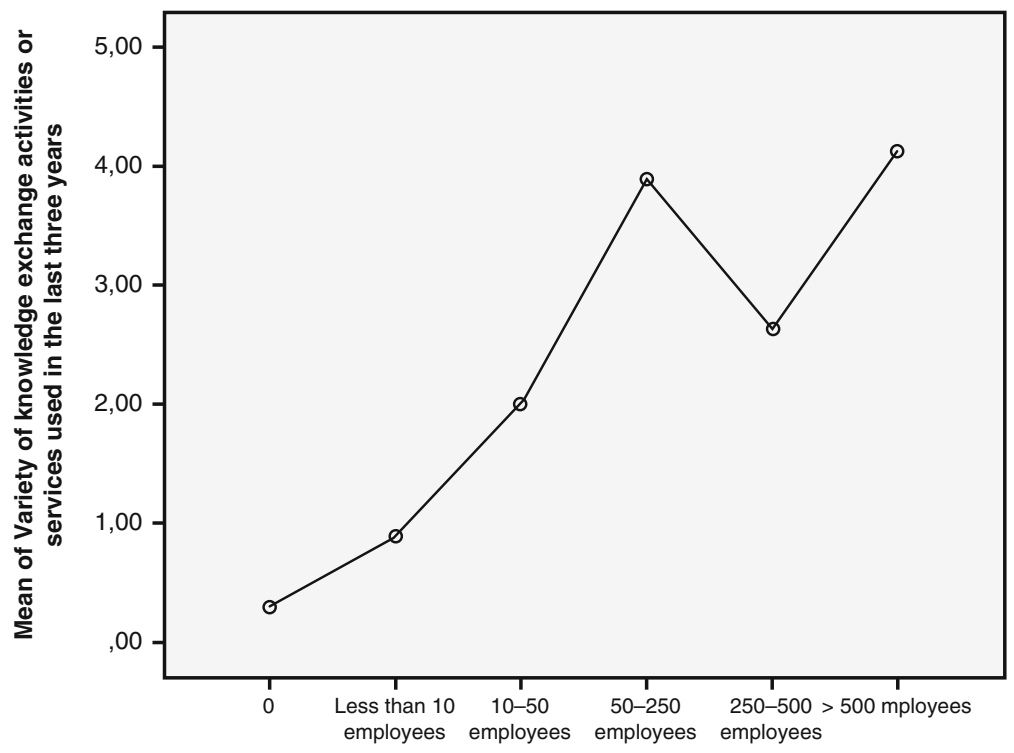

16. What is the size of your organization?

Fig. 4.3 Variety of utilisation and provision by size. Source: Own elaboration

In our sample, $36.3 \%$ of the organizations provided or administered knowledge exchange services or schemes (dummy variable 'KManag'). We used Chi-Square association tests to verify if entities that managed or administered these kinds 
of innovation services or schemes felt differently the variation in their utilisation and provision. We detected a significant association between these variables (cf. Appendix).

Using the non-parametric Mann-Whitney test we also have found that universities and other PROs are different of other types of organizations regarding their utilization and provision of knowledge services (cf. Appendix).

\subsubsection{Econometric Evidence}

In this section, we intend to consider a specific approach to resilience, by focusing the resilience of innovation. As explained before, in our understanding resilience of innovation operates at different levels, from the regional system to the innovation actors. The notion of resilience of innovation at system-level regards the capacity of a specific innovation system to deal with a negative disruption (external or systemic) and continue or improve its function. A strict and operational definition of innovation systems' resilience can be the capacity of the system to maintain innovative activities avoiding structural negative impacts of economic crises, namely those deriving from the contraction of regional product and the rise of unemployment. At micro-level, resilience of innovation regards the capacity of the firm or other relevant actor to continue or to improve innovative efforts despite external and internal shocks.

Based on these results the next step was to create a model that could explain the resilience of innovation in the organizations. For this purpose we considered as an operational definition, those organizations that experienced an increased or the equal demand of innovation and knowledge-based services during the last 3 years. A new binary variable was created with this objective. Then we transformed some the previously presented variables in more readable "dummies" for econometric analysis. ${ }^{6}$

The model used a Probit estimator. The results of three versions of the estimation are provided in the Table 4.3 below.

The model tries to assess the influence that internal (organizational related factors), external factors, and the innovation and knowledge services have in organization to the resilience of its innovation process. External factors refer to the context (cluster/ environment in which the organizations operate), encapsulated by the market variation (MARKET_VARIATION), to detect the general situation, and the assessment of the quality of the services (EVAL) as a proxy of the sophistication of the existing supply. Internal factors relate to organizational capabilities, and are represented by types of clients, exports, size, academic profile, knowledge management. We also pay attention to the influence of the breadth of utilization (USE) and provision (PROVI$\mathrm{SION}$ ) of innovation and knowledge services to the resilience of the process.

\footnotetext{
6"SIZE_BIG" is a binary variable that assumes the value 1 if the organization has 250 or more workers. "UNIV_PROS" assumes 1 if organization is a university or other PRO. "MARKET_VARIATION" is a dummy that assumes value 1 if organizations believe that their market experienced an increased or at least an equal demand of innovation and knowledge-based services during the last 3 years.
} 
Table 4.3 Probit model

\begin{tabular}{|c|c|c|c|}
\hline Variable & $\begin{array}{l}\text { Model } \\
1 \text { Global } \\
\end{array}$ & $\begin{array}{l}\text { Model } 2 \text { Eliminated } \\
\text { non-significant } \\
\text { variables }\end{array}$ & $\begin{array}{l}\text { Model } 3 \text { Market } \\
\text { variation effects } \\
\text { eliminated }\end{array}$ \\
\hline $\mathrm{C}$ & $-2.573697 * * *$ & $-2.542377 * * *$ & $-1.908418 * * *$ \\
\hline \multicolumn{4}{|l|}{ External factors } \\
\hline MARKET_VARIATION & $3.515976^{* * *}$ & $3.335156^{* * *}$ & - \\
\hline EVAL & $0.083005 * * *$ & $0.080570 * * *$ & $0.062051 * * *$ \\
\hline \multicolumn{4}{|l|}{ Internal factors } \\
\hline CLIENT_FIRM & -0.003265 & - & - \\
\hline CLIENT_EXPORT & $0.054807 * *$ & $0.048929 *$ & 0.026621 \\
\hline SIZE_BIG & $1.503512 * *$ & $1.855549 * * *$ & $1.272323 * * *$ \\
\hline UNIV_PROS & 0.681733 & - & - \\
\hline KMANAG & $-1.910828 * *$ & $-1.681732 * *$ & 0.723818 \\
\hline \multicolumn{4}{|c|}{ Innovation and knowledge services } \\
\hline USE & $0.252214 * *$ & $0.254233 * *$ & $0.192370 * *$ \\
\hline PROVISION & $-0.565364 * * *$ & $-0.540563 * * *$ & $-0.173323^{*}$ \\
\hline
\end{tabular}

Source: Own elaboration

61 Obs with Dep $=0 ; 41$ Obs with Dep $=1$

$*$ Significant at $0.1, * *$ significant at $0.05, * * *$ significant at 0.01

Our exploratory results suggest that in terms of internal factors, the resilience of innovation is positively influenced by size and by exports. The fact that organizations manage innovation or knowledge exchange schemes is statistically significant but with a negative impact.

The influence of the breadth of innovation and knowledge services shows an interesting effect. While organizations that use a larger number of types of services have more resilient innovation processes, the provision of a larger number of types of services has a negative impact on their demand.

\subsection{Conclusion}

The maritime cluster is of particular interest for the European Union as an area of potential economic valorisation connecting traditional sectors with science-based activities. In this chapter, drawing upon empirical date on the knowledge provision and needs of maritime cluster innovative organizations in the European Atlantic Area, we have provided econometric evidence of the main internal and external factors that influence the resilience of innovation at the organizational level. We defined 'resilience of innovation' as the multi-level capacity of the innovation process to maintain or accelerate its functions when facing an internal disruption or an external shock.

In terms of internal factors, the resilience of innovation at organizational level is positively influenced by size-this confirms ideas found in the literature i.e. small firms have more difficulties in being innovative, and by exports-suppliers' interaction favour knowledge exchange and creation, also supported by existing literature 
on learning and supply chains. The fact that the dummy variable that regards to organizations that manage innovation or knowledge exchange schemes is statistically significant but with a negative impact could be due to opportunity cost of dedicating time to managing: time and managerial attention are scarce resources.

Regarding the influence of the breadth of innovation and knowledge services, our results indicate that organizations that use a larger number of types of services have more resilient innovation processes, this could be because these organizations are innovative resilient. They use this variety to generate knowledge.

The provision of a larger number of types of services has a negative impact. Perhaps due to cost of keeping multiple sources at a time of economic crisis when less variety is demanded in general, by most organizations (even if those among them that are resilient demand it).

Our results confirm the relevance of innovation and knowledge service provision. Even —or particularly more so-in times of economic crisis, increasing access to these services is key considering the importance of these services for the resilience of innovation. This suggests a need to better communicate to firms, particularly small firms, the availability of such services and improve the alignment and accessibility of these services by the smallest firms.

Regional policy actors may consider expanding and better connecting the network of service provision with the needs of firms and providing additional funding and other incentives to encourage the use of these services, for instance by using mechanisms such as innovation vouchers.

Some organizations have witnessed an increase of demand for their services. These activities could be further promoted and enabled, through public programmes for knowledge transfer and technology extension infrastructure, including efforts to build up long-term capacity for the provision of services that are customized to the needs of client firms, yet adaptive and flexible, as well as the development of good knowledge exchange networks between clients, service providers and other resources.

In some peripheral areas, local and regional universities tend to partly compensate for the relative lack of other private knowledge intensive service and venture capital providers regionally and their role in enabling innovation of local enterprises should be acknowledged and supported by public policy. Firms would also benefit from the reduction of red tape and unnecessary bureaucracy associated with innovation support. Finally, firms, particularly micro enterprises, may lack the absorptive capacity to benefit from the presence of innovation support infrastructure, particularly research-intensive activities from universities. A clearer development pathway may be promoted that builds up the competences of these firms through low-level services and eventually allows an upgrade to more sophisticated, researchintensive activities.

Acknowledgements This chapter was stimulated by KIMERAA-Knowledge transfer to Improve Marine Economy in Regions from the Atlantic Area, project developed between 2011 and 2014, co-financed by the European cooperation program INTERREG Atlantic Area through the ERDF-European Regional Development Fund. The help of project partners in the data collection is gratefully acknowledged. Carla Nogueira benefits from the financial support from FCTPortuguese Science and Technology Foundation (SFRH/BD/117398/2016). Hugo Pinto also acknowledges the financial support from FCT (SFRH/BPD/84038/2012). 


\section{Appendix}

\section{Histogram of Variety of Uses and Provisions}
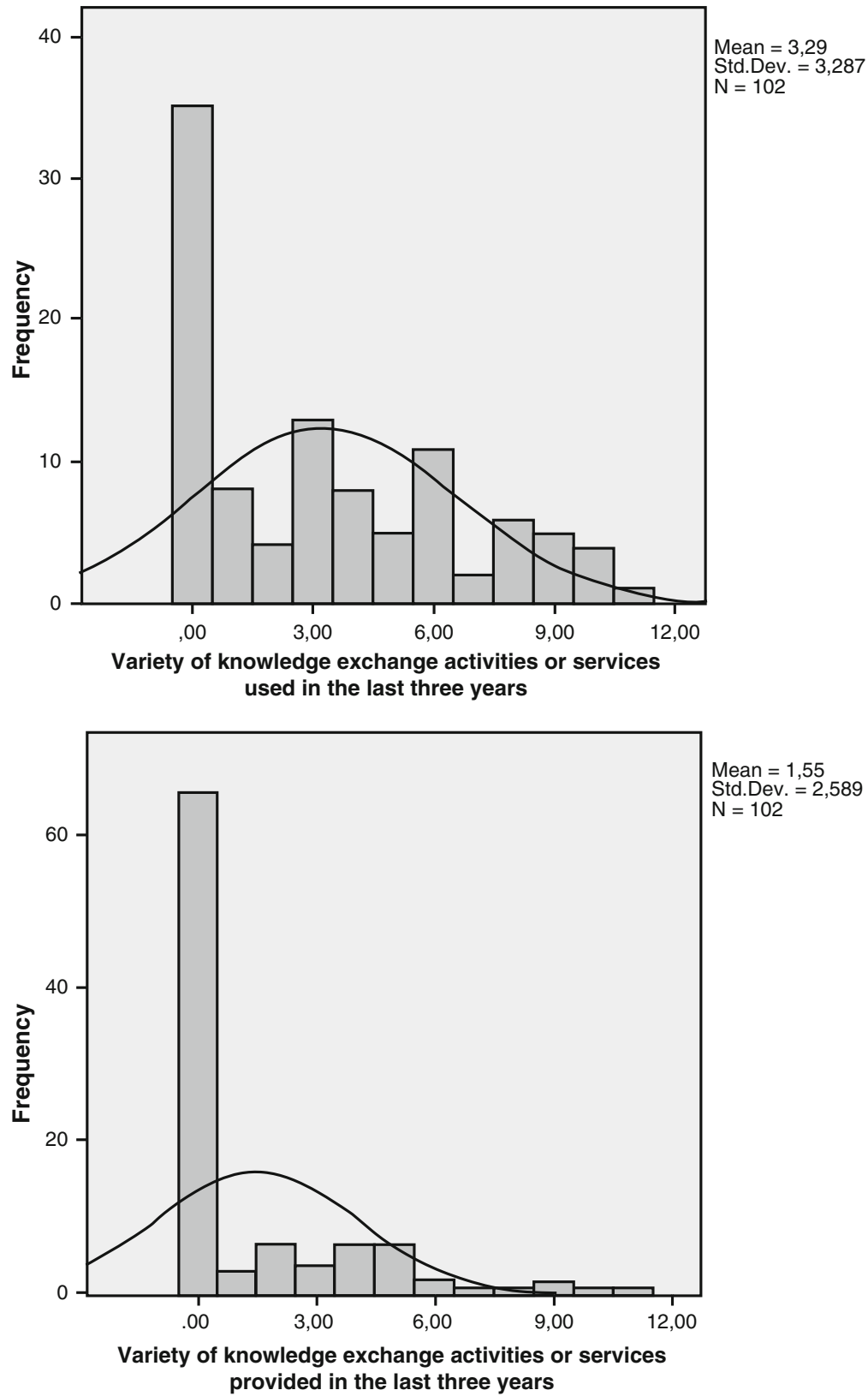

Source: Own elaboration 


\section{Anova}

\begin{tabular}{l|l|r|r|r|r|r}
\hline \multicolumn{2}{l|}{} & $\begin{array}{l}\text { Sum of } \\
\text { squares }\end{array}$ & df & $\begin{array}{l}\text { Mean } \\
\text { square }\end{array}$ & F & Sig. \\
\hline $\begin{array}{l}\text { Variety of knowledge } \\
\text { exchange activities or services }\end{array}$ & Between groups & 423.221 & 5 & 84.644 & 12.165 & .000 \\
\cline { 2 - 9 } \begin{tabular}{l} 
used in the last 3 years \\
\cline { 2 - 9 }
\end{tabular} & Within groups & 667.955 & 96 & 6.958 & & \\
\cline { 2 - 9 } $\begin{array}{l}\text { Variety of knowledge } \\
\text { exchange activities or services } \\
\text { provided in the last 3 years }\end{array}$ & Between groups & 1091.176 & 101 & & & \\
\cline { 2 - 9 } & Within groups & 495.958 & 96 & 5.166 & & .000 \\
\cline { 2 - 9 } & Total & 677.255 & 101 & & & \\
\hline
\end{tabular}

Source: Own elaboration

\section{Kruskal-Wallis Test}

\begin{tabular}{|c|c|c|c|}
\hline & Size of organization & $\mathrm{N}$ & Mean rank \\
\hline \multirow{7}{*}{$\begin{array}{l}\text { Variety of knowledge } \\
\text { exchange activities or services } \\
\text { used in the last } 3 \text { years }\end{array}$} & 0 & 33 & 29.26 \\
\hline & Less than 10 employees & 28 & 48.00 \\
\hline & 10-50 employees & 13 & 70.08 \\
\hline & 50-250 employees & 9 & 84.61 \\
\hline & 250-500 employees & 11 & 62.09 \\
\hline & $>500$ employees & 8 & 73.50 \\
\hline & Total & 102 & \\
\hline \multirow{7}{*}{$\begin{array}{l}\text { Variety of knowledge } \\
\text { exchange activities or services } \\
\text { provided in the last } 3 \text { years }\end{array}$} & 0 & 33 & 37.80 \\
\hline & Less than 10 employees & 28 & 47.66 \\
\hline & 10-50 employees & 13 & 57.15 \\
\hline & 50-250 employees & 9 & 79.44 \\
\hline & 250-500 employees & 11 & 59.23 \\
\hline & $>500$ employees & 8 & 70.19 \\
\hline & Total & 102 & \\
\hline
\end{tabular}

Source: Own elaboration

\begin{tabular}{l|l|l}
\hline Kruskal Wallis test & $\begin{array}{l}\text { Variety of knowledge } \\
\text { exchange activities or services } \\
\text { used in the last 3 years }\end{array}$ & $\begin{array}{l}\text { Variety of knowledge exchange } \\
\text { activities or services provided } \\
\text { in the last 3 years }\end{array}$ \\
\hline Chi-Square & 43.218 & 27.451 \\
\hline Df & 5 & 5 \\
\hline Asymp. Sig. & 0.000 & 0.000 \\
\hline
\end{tabular}

Source: Own elaboration

Notes: Kruskal Wallis test, Grouping variable: what is the size of your organization? 


\section{Mann-Whitney Test}

\begin{tabular}{l|l|r|l|l}
\hline & Universities and PROs & $\mathrm{N}$ & Mean rank & Sum of ranks \\
\hline \multirow{2}{*}{$\begin{array}{l}\text { Variety of knowledge } \\
\text { exchange activities or services }\end{array}$} & Other & 86 & 47.62 & 4095.50 \\
\cline { 2 - 5 } & University or PRO & 16 & 72.34 & 1157.50 \\
\cline { 2 - 5 } & Total & 102 & & \\
\hline \multirow{2}{*}{$\begin{array}{l}\text { Variety of knowledge } \\
\text { exchange activities or services } \\
\text { provided in the last 3 years }\end{array}$} & Other & 86 & 46.28 & 3980.00 \\
\cline { 2 - 5 } & University or PRO & 16 & 79.56 & 1273.00 \\
\cline { 2 - 5 } & Total & 102 & & \\
\hline
\end{tabular}

Source: Own elaboration

\begin{tabular}{l|l|l}
\hline & $\begin{array}{l}\text { Variety of knowledge } \\
\text { exchange activities or } \\
\text { services used in the last } \\
\text { 3 years }\end{array}$ & $\begin{array}{l}\text { Variety of knowledge } \\
\text { exchange activities or services } \\
\text { provided in the last 3 years }\end{array}$ \\
\hline Mann-Whitney U & 354.500 & 239.000 \\
\hline Wilcoxon W & 4095.500 & 3980.000 \\
\hline Z & -3.140 & -4.842 \\
\hline Asymp. Sig. (2-tailed) & 0.002 & 0.000 \\
\hline
\end{tabular}

Source: Own elaboration

Note: Grouping variable: Universities and PROs

\section{Tests for Independence}

Association of between "Does your organization provide or administer any knowledge exchange services or schemes?: * Variety of knowledge exchange activities or services used in the last 3 years".

\section{Chi-square tests}

\begin{tabular}{l|l|l|l}
\hline & Value & df & Asymp. Sig. (2-sided) \\
\hline Pearson Chi-square & $103.831^{\mathrm{a}}$ & 33 & 0.000 \\
\hline Likelihood ratio & 112.200 & 33 & 0.000 \\
\hline Linear-by-linear association & 5.112 & 1 & 0.024 \\
\hline N of valid cases & 102 & & \\
\hline
\end{tabular}

Source: Own elaboration

${ }^{\mathrm{a}} 45$ cells $(93.8 \%)$ have expected count less than 5 . The minimum expected count is 0.04

\begin{tabular}{|c|c|c|c|}
\hline \multicolumn{4}{|l|}{ Symmetric measures } \\
\hline & & Value & Approx. Sig. \\
\hline Nominal by nominal & Contingency coefficient & 0.710 & 0.000 \\
\hline \multicolumn{2}{|l|}{$\mathrm{N}$ of valid cases } & 102 & \\
\hline
\end{tabular}

Source: Own elaboration 
Association between "Does your organization provide or administer any knowledge exchange services or schemes? * Variety of knowledge exchange activities or services provided in the last 3 years".

Chi-square tests

\begin{tabular}{l|l|l|l}
\hline & Value & df & Asymp. Sig. (2-sided) \\
\hline Pearson Chi-square & $97.740^{\mathrm{a}}$ & 33 & 0.000 \\
\hline Likelihood ratio & 123.252 & 33 & 0.000 \\
\hline Linear-by-linear association & 1.394 & 1 & 0.238 \\
\hline N of valid cases & 102 & &
\end{tabular}

Source: Own elaboration

${ }^{\mathrm{a}} 45$ cells $(93.8 \%)$ have expected count less than 5 . The minimum expected count is 0.04

\begin{tabular}{l|l|l|l}
\hline \multicolumn{2}{l}{ Symmetric measures } & Value & Approx. Sig. \\
\hline Nominal by nominal & Contingency coefficient & 0.700 & 0.000 \\
\hline N of valid cases & 102 & \\
\hline
\end{tabular}

Source: Own elaboration

\section{Predictive Capacity of Probit Model}

Model in E-Views: resilience c client_firm clients_export size_big univ_pros kmanag eval use provision market_variation.

\section{Global Model}

\begin{tabular}{l|l|l|l}
\hline Mean dependent var & 0.401961 & S.D. dependent var & 0.492715 \\
\hline S.E. of regression & 0.309832 & Akaike info criterion & 0.711688 \\
\hline Sum squared resid & 8.831618 & Schwarz criterion & 0.969038 \\
\hline Log likelihood & -26.29607 & Hannan-Quinn criter. & 0.815898 \\
\hline Restr. log likelihood & -68.72747 & Avg. log likelihood & -0.257805 \\
\hline LR statistic (9 df) & 84.86279 & McFadden R-squared & 0.617386 \\
\hline Probability(LR stat) & $1.74 \mathrm{E}-14$ & & \\
\hline Obs with Dep $=0$ & 61 & Total obs & 102 \\
\hline Obs with Dep $=1$ & 41 & & \\
\hline Source: Own
\end{tabular}

Source: Own elaboration 


\begin{tabular}{|c|c|c|c|c|c|c|}
\hline \multicolumn{7}{|c|}{ Global model prediction evaluation (success cutoff $\mathrm{C}=0.5$ ) } \\
\hline & \multicolumn{3}{|c|}{ Estimated equation } & \multicolumn{3}{|c|}{ Constant probability } \\
\hline & Dep $=0$ & Dep $=1$ & Total & Dep $=0$ & Dep $=1$ & Total \\
\hline $\mathrm{P}($ Dep $=1)<=\mathrm{C}$ & 55 & 7 & 62 & 61 & 41 & 102 \\
\hline $\mathrm{P}(\mathrm{Dep}=1)>\mathrm{C}$ & 6 & 34 & 40 & 0 & 0 & 0 \\
\hline Total & 61 & 41 & 102 & 61 & 41 & 102 \\
\hline Correct & 55 & 34 & 89 & 61 & 0 & 61 \\
\hline$\%$ Correct & 90.16 & 82.93 & 87.25 & 100.00 & 0.00 & 59.80 \\
\hline$\%$ Incorrect & 9.84 & 17.07 & 12.75 & 0.00 & 100.00 & 40.20 \\
\hline Total Gain ${ }^{a}$ & -9.84 & 82.93 & 27.45 & & & \\
\hline \multirow[t]{3}{*}{ Percent Gain ${ }^{\mathrm{b}}$} & NA & 82.93 & 68.29 & & & \\
\hline & \multicolumn{3}{|c|}{ Estimated equation } & \multicolumn{3}{|c|}{ Constant probability } \\
\hline & Dep $=0$ & Dep $=1$ & Total & Dep $=0$ & Dep $=1$ & Total \\
\hline $\mathrm{E}(\#$ of Dep $=0)$ & 52.69 & 8.58 & 61.27 & 36.48 & 24.52 & 61.00 \\
\hline $\mathrm{E}(\#$ of Dep $=1)$ & 8.31 & 32.42 & 40.73 & 24.52 & 16.48 & 41.00 \\
\hline Total & 61.00 & 41.00 & 102.00 & 61.00 & 41.00 & 102.00 \\
\hline Correct & 52.69 & 32.42 & 85.11 & 36.48 & 16.48 & 52.96 \\
\hline$\%$ Correct & 86.38 & 79.07 & 83.44 & 59.80 & 40.20 & 51.92 \\
\hline$\%$ Incorrect & 13.62 & 20.93 & 16.56 & 40.20 & 59.80 & 48.08 \\
\hline Total Gain $^{\mathrm{a}}$ & 26.57 & 38.87 & 31.52 & & & \\
\hline Percent Gain ${ }^{\mathrm{b}}$ & 66.11 & 65.00 & 65.56 & & & \\
\hline
\end{tabular}

Source: Own elaboration

aChange in "\% Correct" from default (constant probability) specification

${ }^{\mathrm{b}}$ Percent of incorrect (default) prediction corrected by equation

\section{References}

Alexander, D. E. (2013). Resilience and disaster risk reduction: An etymological journey. Natural Hazards and Earth System Sciences, 13(11), 2707-2716. https://doi.org/10.5194/nhess-132707-2013

Archibugi, D., Filippetti, A., \& Frenz, M. (2013). Economic crisis and innovation: Is destruction prevailing over accumulation? Research Policy, 42(2), 303-314. https://doi.org/10.1016/j. respol.2012.07.002

Asheim, B. T., Coenen, L., Moodysson, J. \& Vang, J. (2005). Regional innovation system policy: A knowledge-based approach. Papers in Innovation Studies 2005/13, Lund University, CIRCLE Center for Innovation, Research and Competences in the Learning Economy.

Asheim, B. T., Smith, H. L., \& Oughton, C. (2011). Regional innovation systems: Theory, empirics and policy. Regional Studies, 45(7), 875-891. https://doi.org/10.1080/00343404.2011.596701

Bellini, N. (2003). Business support services: Marketing and the practice of regional innovation policy. Cork: Oak Tree Press.

Bluhm, K., \& Schmidt, R. (2008). Change in SMEs - The new European capitalism. Basingstoke: Palgrave Macmillan. https://doi.org/10.1057/9780230227781

Boschma, R. (2005). Proximity and innovation: A critical assessment. Regional Studies, 39(1), 61-74. https://doi.org/10.1080/0034340052000320887

Boschma, R. (2015). Towards an evolutionary perspective on regional resilience. Regional Studies, 49(5), 733-751. https://doi.org/10.1080/00343404.2014.959481 
Boschma, R., \& Martin, R. (2010). The aims and scope of evolutionary economic geography. Papers in Evolutionary Economic Geography (PEEG). Retrieved from http://ideas.repec.org/p/ egu/wpaper/1001.html

Cooke, P. (2013). Complex adaptive innovation systems: Relatedness and transversality in the evolving region. Oxford: Routledge.

Cooke, P., \& Leydesdorff, L. (2006). Regional development in the knowledge-based economy: The construction of advantage. Journal of Technology Transfer, 31, 5-15.

Davoudi, S., Shaw, K., Haider, L. J., Quinlan, A. E., Peterson, G. D., Wilkinson, C., et al. (2012). Resilience: A bridging concept or a dead end? "reframing" resilience: Challenges for planning theory and practice interacting traps: Resilience assessment of a pasture management system in Northern Afghanistan urban resilience: What does it mean in Planni. Planning Theory \& Practice, 13(2), 299-333.

Doloreux, D. (2002). What we should know about regional systems of innovation. Technology in Society, 24(3), 243-263.

Fernández-Esquinas, M., Pinto, H., Yruela, M. P., \& Pereira, T. S. (2015). Tracing the flows of knowledge transfer: Latent dimensions and determinants of university-industry interactions in peripheral innovation systems. Technological Forecasting and Social Change. https://doi.org/ 10.1016/j.techfore.2015.07.013

Frenken, K., Van Oort, F., \& Verburg, T. (2007). Related variety, unrelated variety and regional economic growth. Regional Studies, 41(5), 685-697. https://doi.org/10.1080/00343400601120296

Frenz, M., \& Prevezer, M. (2012). What can CIS data tell us about technological regimes and persistence of innovation? Industry and Innovation, 19(4), 285-306. https://doi.org/10.1080/ 13662716.2012 .694676

Gertler, M. S. (2003). Tacit knowledge and the economic geography of context, or the undefinable tacitness of being (there). Journal of Economic Geography, 3(1), 75-99.

Hamdouch, A., \& Depret, M. (2012). Mondialisation et résilience des territoires. Québec: Presses de l'Université du Québec.

Hassink, R. (1997). Technology and transfer infrastructures: Some lessons from experiences in Europe, the US and Japan. European Planning Studies, 5, 351-370.

Howells, J. (2005). Innovation and regional economic development: A matter of perspective? Research Policy, 34(8), 1220-1234. https://doi.org/10.1016/j.respol.2005.03.014

Laursen, K., \& Salter, A. (2006). Open for innovation: The role of openness in explaining innovation performance among U.K. manufacturing firms. Strategic Management Journal, 27 (2), 131-150. https://doi.org/10.1002/smj.507

Makkonen, T. (2013). Government science and technology budgets in times of crisis. Research Policy, 42(3), 817-822. https://doi.org/10.1016/j.respol.2012.10.002

Martin, R., \& Sunley, P. (2015). On the notion of regional economic resilience: Conceptualization and explanation. Journal of Economic Geography, 15, 1-42. https://doi.org/10.1093/jeg/lbu015

Paunov, C. (2012). The global crisis and firms' investments in innovation. Research Policy, 41(1), 24-35. https://doi.org/10.1016/j.respol.2011.07.007

Perkmann, M., Tartari, V., McKelvey, M., Autio, E., Broström, A., D’Este, P., et al. (2013). Academic engagement and commercialisation: A review of the literature on university-industry relations. Research Policy, 42(2), 423-442. https://doi.org/10.1016/j.respol.2012.09.007

Pinto, H., \& Fernández-Esquinas, M. (2013). Exploring knowledge-transfer dynamics in a South European region: Breadth, intensity and informality of university-industry interactions in Andalusia: Knowledge commercialization and valorization in regional economic development. In T. Baycan (Ed.), Knowledge commercialization and valorization in regional economic development. Edward Elgar. Retrieved from http://www.elgaronline.com/abstract/9781781004067. 00018.xml

Pinto, H., \& Pereira, T. S. (2014). Resiliência dos sistemas de inovação face à turbulência económica. Oficina Do CES, 418 Retrieved from http://www.ces.uc.pt/publicacoes/oficina/ index.php?id=11157 
Pinto, H., Cruz, A. R., \& Combe, C. (2015a). Cooperation and the emergence of maritime clusters in the Atlantic: Analysis and implications of innovation and human capital for blue growth. Marine Policy, 57, 167-177. https://doi.org/10.1016/j.marpol.2015.03.029

Pinto, H., Fernandez-Esquinas, M., \& Uyarra, E. (2015b). Universities and knowledge-intensive business services (KIBS) as sources of knowledge for innovative firms in peripheral regions. Regional Studies, 49(11), 1873-1891. https://doi.org/10.1080/00343404.2013.857396

Rodríguez-Pose, A. (2013). Do institutions matter for regional development? Regional Studies, 47 (7), 1034-1047. https://doi.org/10.1080/00343404.2012.748978

Shapira, P., Uyarra, E., Youtie, J., Cox, D., Gok, A., Rogers, J., et al. (2015). Institutions for Technology Diffusion, USA. Inter-American Development Bank, Competitiveness and Innovation Division. Report No. IDB-TN-832.

Simmie, J. (2014). Regional economic resilience: A Schumpeterian perspective. Raumforschung und Raumordnung, 72(2), 103-116. https://doi.org/10.1007/s13147-014-0274-y

Simmie, J., \& Martin, R. L. (2010). The economic resilience of regions: Towards an evolutionary approach. Cambridge Journal of Regions Economy and Society, 3, $27-43$.

Skålholt, A., \& Thune, T. (2013). Coping with economic crises-The role of clusters. European Planning Studies, 22(10), 1993-2010. https://doi.org/10.1080/09654313.2013.813909

Teixeira, A. C., Santos, P., \& Oliveira Brochado, A. (2008). International R\&D cooperation between low-tech SMEs: The role of cultural and geographical proximity. European Planning Studies, 16(6), 785-810. https://doi.org/10.1080/09654310802079411

Tödtling, F., \& Trippl, M. (2005). One size fits all? Research Policy, 34(8), 1203-1219. https://doi. org/10.1016/j.respol.2005.01.018

Torre, A., \& Rallet, A. (2005). Proximity and localization. Regional Studies, 39(1), 47-59. https:// doi.org/10.1080/0034340052000320842

Uyarra, E., \& Flanagan, K. (2012). Reframing regional innovation systems: Evolution, complexity and public policy. In P. Cooke (Ed.), Re-framing regional development (pp. 146-163). London: Routledge.

Zeng, S. X., Xie, X. M., \& Tam, C. M. (2010). Relationship between cooperation networks and innovation performance of SMEs. Technovation, 30(3), 181-194. https://doi.org/10.1016/j. technovation.2009.08.003 